\title{
Spawning areas and larval distributions of anchovy Engraulis encrasicolus in relation to environmental conditions in the Gulf of Tunis (Central Mediterranean Sea)
}

\author{
RAFIK ZARRAD ${ }^{1}$, HECHMI MISSAOUI ${ }^{2,3}$, FRANCISCO ALEMANY ${ }^{4}$, \\ ROMDHANE MOHAMED SALAH ${ }^{2}$, ALBERTO GARCÍA ${ }^{4}$, M'RABET RIDHA ${ }^{1}$, \\ JARBOUI OTHMAN ${ }^{1}$ and EL ABED AMOR ${ }^{2}$ \\ ${ }^{1}$ Institut National des Sciences et Technologies de la Mer (INSTM), Port de pêche La Goulette, 2060 La Goulette, Tunis, \\ Tunisie.E-mail: rafik.zarrad@instm.rnrt.tn \\ ${ }^{2}$ Institut National Agronomique de Tunisie, \\ Institut Supérieur de la Pêche et de l'Aquaculture de Bizerte, \\ ${ }^{4}$ Instituto Español de Oceanografía.
}

\begin{abstract}
SUMMARY: Early life stages of anchovy were investigated in the Gulf of Tunis by means of four seasonal surveys carried out from summer 2002 to spring 2003. Anchovy eggs and larvae were found all year round, but they were much more abundant in spring and summer. In spring, the main spawning area was located in the north of the Gulf, to the west and southwest of Zembra Island. In summer, higher egg and larva abundances were also observed to the southwest of Zembra Island, but secondary spawning grounds were detected in the vicinity of the mouths of the Rivers Majreda and Meliane. No direct correlations between sea surface temperature (SST), salinity (SSS) and chlorophyll $a$ and the horizontal distribution of eggs and larvae were observed. However, egg distributions in all seasons and larval distributions in summer and autumn were significantly related to depth. The temporal variation of temperature seems to control the spawning intensity and the beginning of spawning seems to be triggered by the increase in SST.
\end{abstract}

Keywords: eggs, larvae, Engraulis encrasicolus, spawning area, Gulf of Tunis.

RESUMEN: ÁREAS DE PUESTA Y DISTRIBUCIÓN LARVARIA DE ANCHOA ENGRAULIS ENCRASICOLUS EN RELACIÓN CON LAS CONDICIONES AMBIENTALES EN El GOLFo DE TÚNEZ (MEDITERRÁNEO CENTRAL). - Se estudiaron los huevos y larvas de anchoa en el Golfo de Túnez por medio de cuatro campañas estacionales llevadas a cabo entre verano del 2002 y primavera del 2003. Los huevos y larvas de anchoa se encontraron a lo largo de todo el año; pero fueron mucho más abundantes en primavera y verano. En primavera, la principal área de puesta se localizó en el norte del Golfo, al oeste y suroeste de la isla de Zembra. En verano, las mayores concentraciones de huevos y larvas también se encontraron en el suroeste de la isla de Zembra; pero se detectaron áreas de puesta secundarias cerca de las desembocaduras de los ríos Majreda y Meliane. No se encontraron correlaciones directas entre la temperatura superficial (SST), la salinidad (SSS) y la clorofila a y la distribución horizontal de huevos y larvas de anchoa. Sin embargo, la distribución de huevos, durante todo el año, y las distribuciones larvarias, en verano y otoño, se relacionaron de forma significativa con la profundidad. La variación temporal de la temperatura parece controlar la intensidad de la puesta y el inicio de la freza parece dispararse por el incremento de la SST.

Palabras clave: huevos, larvas, anchoa, Engraulis encrasicolus, zonas de puesta, Golfo de Túnez.

\section{INTRODUCTION}

The stock fluctuations of small pelagic species (e.g. sardine and anchovy) are often attributed to the relative success of recruitment. The variability of this success takes place in early life stages through the action of environmental factors. Indeed, physical processes (enrichment, concentration and reten- 
tion) play a key role in this success, which combines to yield favourable reproductive habitats for small pelagic fishes and also other species (Agostini and Bakun, 2002). While Engraulis encrasicolus spawning of the Iberian Peninsula have been extensively studied and related to the main productive events in the different areas, the information is very scarce for the northern African waters. The variability of the anchovy recruitment in the Bay of Biscay has been mainly explained by upwelling intensity (Borja et $a l .$, 1998). The enrichment assured by Rivers Rhone and Ebro and the development of the deep fluorescence maximum influence northwestern Mediterranean anchovy (García and Palomera, 1996; Olivar et al., 2001; Sabatés et al., 2001; Lloret et al., 2004).

Despite the importance of the small pelagic resources in Tunisian waters, as in other North African Mediterranean areas information on early life stages is very scarce. In Tunisian waters, the first survey to study the abundance and distribution of anchovy eggs was carried out in 1972 by KtariChakroun (1979), while the second one was carried out in 2000 (Zarrad, 2001). These surveys were limited in space and/or time and did not cover either the whole spawning area or the whole spawning period. To overcome this lack of information, a new research program, "ESSATEL", was launched to study early life stages of small pelagic fishes in the gulf of Tunis in relation to environmental factors.

The Tunis Gulf is located in the central Mediterranean Sea. Near this gulf are the Sardinia Channel in the northeast, and the Strait of Sicily in the northwest, where the water exchanges between western and eastern Mediterranean basins occurs. In the Strait of Sicily, surface Modified Atlantic Water (MAW) with low salinity (37.03 to 37.15; Sammari et al., 1999) flows into the eastern Mediterranean, while the Levantine Intermediate Water (LIW) enters the western Mediterranean. The Tunis Gulf receives the outflow of the most important River in Tunisia: the Majreda River situated on the western coast of the Gulf.

According to Agostini and Bakun (2002), the prevailing westerly winds produce coastal upwelling off the south coasts of Sicily and Sardinia and downwelling occurs along the eastern coast of Tunisia. The Ekman transport field carries water from the upwelling (enrichment) zone towards the downwelling (concentration) zone along the east and north coast of Tunisia. The topography of the
Tunisian coast creates protected areas (gulfs of Tunis and Hammamet), which also support concentration, accumulation of chlorophyll and retention areas for pelagic eggs and larvae, such as those of anchovy, by providing shelter from surface currents and wind mixing.

Among the small pelagic species, anchovy (Engraulis encrasicolus) represents 6\% (6000 t) of small pelagic exploitable biomass (100000 t) in Tunisia (Ben Abdallah and Gaamour, 2004). This species is considered under-exploited in Tunisian waters, with a current landing of the order of $380 \mathrm{t}$ per year (DGPA, 1999-2004). Influenced by its economic importance in European markets, a revision of the Tunisian fisheries policy was carried out in order to improve the exploitation of this resource. However, the sustainability of the resource must rely on appropriate management measures based on sound scientific advice arising from research of the whole life cycle (egg, larval development, juvenile and adult).

This paper presents the first information on the seasonal horizontal distribution and the levels of abundance of anchovy eggs and larvae in the Gulf of Tunis and their relationship with sea surface temperature, salinity, chlorophyll $a$ and depth.

\section{MATERIAL AND METHODS}

Four multidisciplinary surveys were carried out on board the R/V Hannibal, one in each season: in summer (from 26 to 30 August 2002), in autumn (from 21 to 25 October 2002), in winter (from 13 to 17 February 2003) and in spring (from 11 to 15 April 2003). Samples were taken on a regular grid of 27 stations (4.8 miles in east-west and 6 miles in northsouth direction) covering the whole Gulf of Tunis. Two additional stations were located near the mouths of the Rivers Majreda and Meliane (Fig. 1).

Temperature and salinity were measured at the surface for each station by means of a WTW conductimeter. Seawater samples for chlorophyll $a$ analysis were obtained with a Niskin bottle at the surface. These samples were filtered through a Whatman GF/C glass fibre, which was frozen at $-20^{\circ} \mathrm{C}$. Chlorophyll $a$ was determined using the conventional technique proposed by Lorenzen (1967). After $90 \%$ acetone extraction, chlorophyll $a$ was measured colorimetrically using a Jenway model 6405UV visible spectrophotometer. 

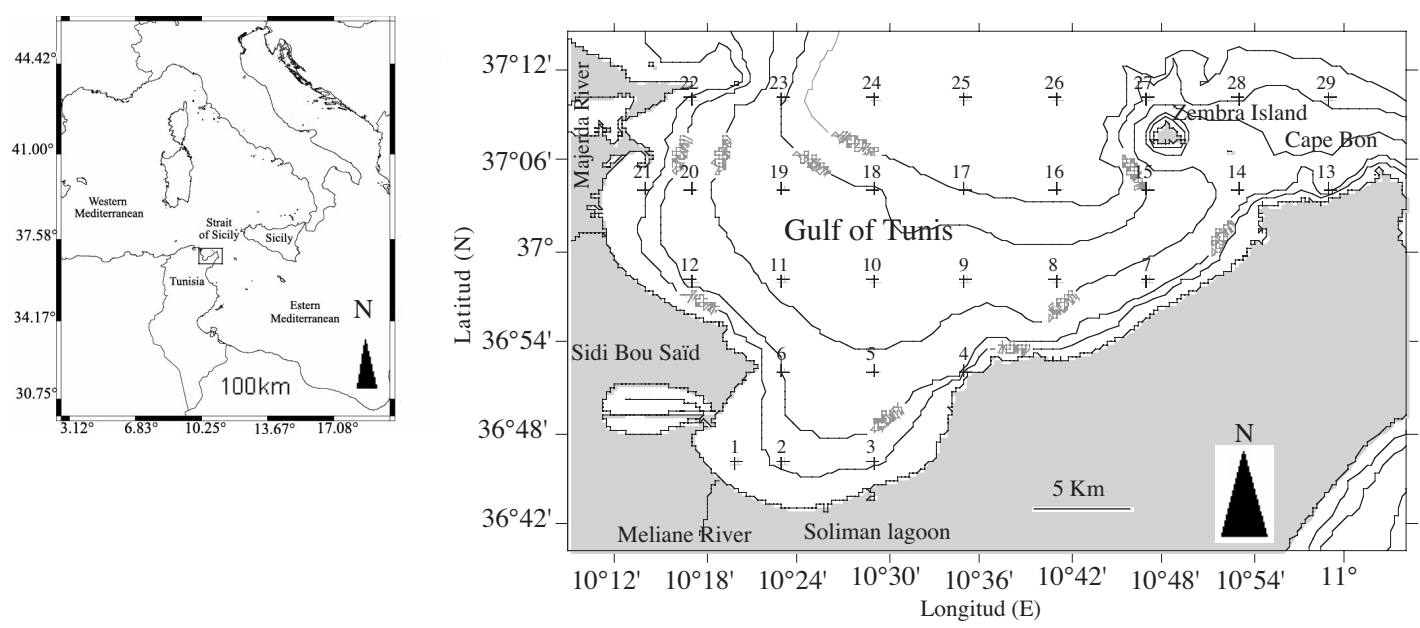

FIG. 1. - Study area and sampling stations.

Plankton samples were taken by oblique tows with a $60 \mathrm{~cm}$ mouth diameter bongo gear, fitted with nets of $335 \mu \mathrm{m}$ mesh size. The vessel speed was 3 knots. Maximum sampled depth was $100 \mathrm{~m}$, wherever possible, or $5 \mathrm{~m}$ above the bottom in shallower waters. A HydroBios flowmeter was fitted in the net mouth to determine the volume of filtered water. Following each tow, the plankton samples were preserved in $4 \%$ formaldehyde solution buffered with borax to maintain $\mathrm{pH}$ around 8.2. Subsequently, anchovy eggs and larvae were sorted. Larval standard length (SL) was measured to the nearest 0.1 $\mathrm{mm}$ using a stereomicroscope fitted with a micrometer. Length frequency distributions were presented as mean abundance of positive stations.

Numbers of eggs and larvae at each station were standardised to the number beneath a $10 \mathrm{~m}^{2}$ area of sea surface using the computed volume of water filtered and depth sampled (Smith and Richardson, 1977). Maps of environmental parameters and anchovy egg and larva abundance distributions were made by means of Surfer Golden Software Inc., applying the kriging interpolation method. Correlation coefficient analysis was performed

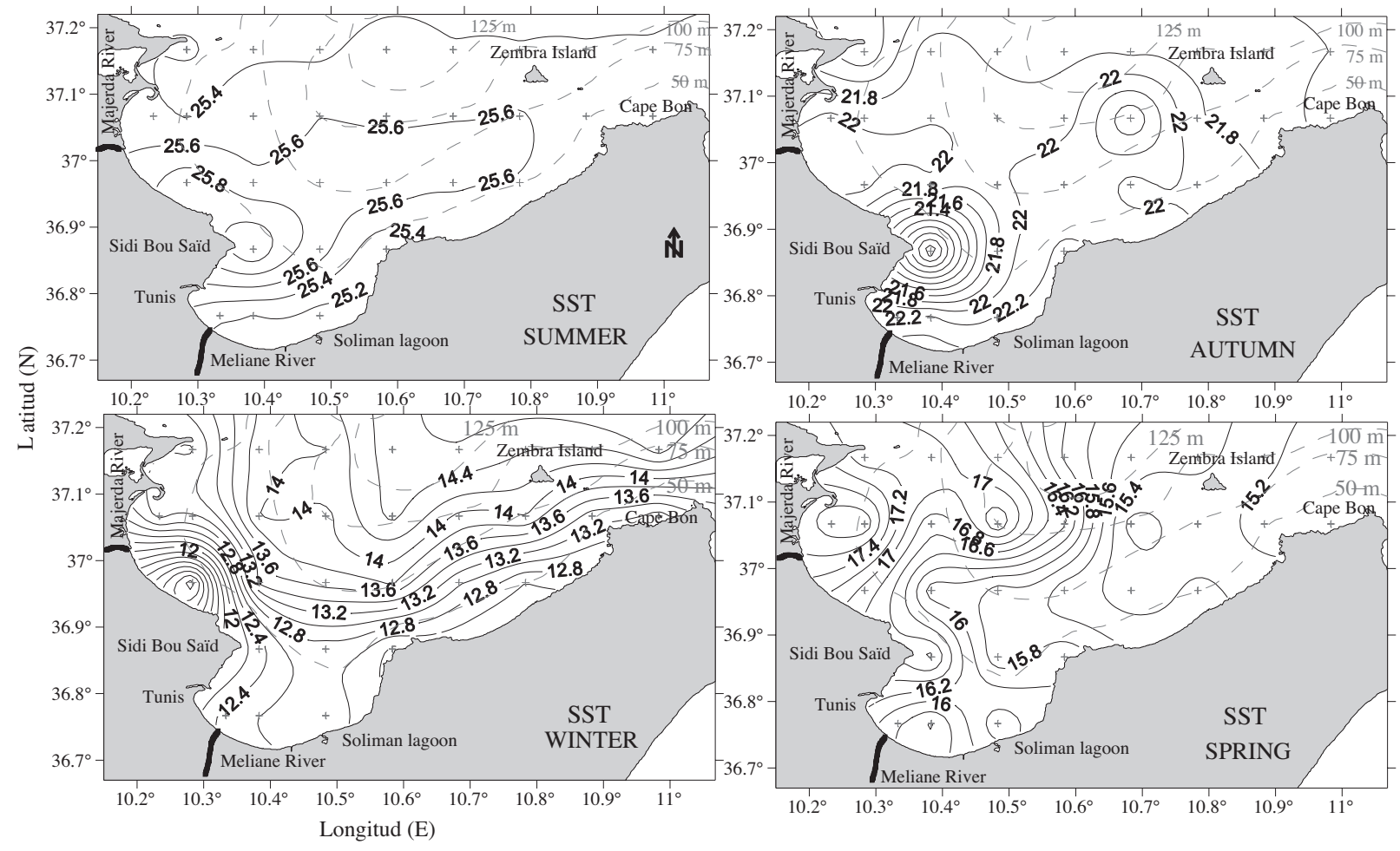

FIG. 2. - Seasonal spatial distribution of sea surface temperature $\left({ }^{\circ} \mathrm{C}\right)$ in the Gulf of Tunis. 
140 - R ZARRAD et al.

TABLE 1. - Range, mean and standard deviation (SD) of temperature, salinity and chlorophyll $a$ by season in the Gulf of Tunis (from summer 2002 to spring 2003).

\begin{tabular}{|c|c|c|c|c|c|c|c|c|c|}
\hline \multirow[b]{2}{*}{ Season } & \multirow[b]{2}{*}{ range } & \multirow{2}{*}{$\underset{\text { mean }}{\text { Temperature }\left({ }^{\circ} \mathrm{C}\right)}$} & \multirow[b]{2}{*}{$\pm \mathrm{SD}$} & \multirow[b]{2}{*}{ range } & \multirow{2}{*}{$\begin{array}{l}\text { Salinity } \\
\text { mean }\end{array}$} & \multirow[b]{2}{*}{$\pm \mathrm{SD}$} & \multicolumn{3}{|c|}{ Chloropyll- $a\left(\mathrm{mg} / \mathrm{m}^{3}\right)$} \\
\hline & & & & & & & range & mean & $\pm \mathrm{SD}$ \\
\hline Summer & $25.1-26.2$ & 25.5 & 0.22 & $37.1-37.8$ & 37.3 & 0.18 & $0.06-1.15$ & 0.41 & 0.26 \\
\hline Autumn & $20.0-22.6$ & 21.8 & 0.45 & $37.0-37.5$ & 37.2 & 0.16 & $0.10-1.35$ & 0.43 & 0.30 \\
\hline Winter & $10.5-14.7$ & 13.4 & 0.93 & $22.3-36.4$ & 35.1 & 2.58 & $0.09-2.30$ & 1.11 & 0.46 \\
\hline Spring & $15.0-18.0$ & 16.1 & 0.86 & $29.5-36.8$ & 36.2 & 1.36 & $0.08-2.77$ & 1.27 & 0.87 \\
\hline
\end{tabular}

between egg and larva abundance and environmental parameters using Statistica Software (StatSoft Inc.) at significance levels of $\mathrm{p}<0.05$.

\section{RESULTS}

\section{Hydrography}

In summer, the sea surface temperature (SST) ranged between 25.1 and $26.2^{\circ} \mathrm{C}$, with an average of $25.5^{\circ} \mathrm{C}$. A patch of warmer waters was detected near Cape Sidi Bou Saïd (Fig. 2 and Table 1). In autumn, surface waters were colder, with an average of $21.8^{\circ} \mathrm{C}$, and their horizontal distribution showed more heterogeneity, with a difference between maximum and minimum values of $2.6^{\circ} \mathrm{C}$. The patch of relatively colder water $\left(20^{\circ} \mathrm{C}\right)$ was found near Cape
Sidi Bou Saïd and the patch of warmer water $\left(22.6^{\circ} \mathrm{C}\right)$ was observed to the southwest of Zembra Island. In winter, surface waters were much colder, with an average of $13.4^{\circ} \mathrm{C}$, which represents $8.4^{\circ} \mathrm{C}$ less than in autumn. Major horizontal differences were detected, with a difference of $4.2^{\circ} \mathrm{C}$ between colder waters $\left(10.5^{\circ} \mathrm{C}\right)$, observed in the south-east of River Majreda mouth, and warmer waters, up to $14.7^{\circ} \mathrm{C}$, located in the north of the study area. In spring there was a mean temperature increase of $2.7^{\circ} \mathrm{C}$, reaching an average of $16.1^{\circ} \mathrm{C}$. In this season warmer waters were located north of the River Majreda mouth and the colder waters were around Cape Bon. There was some positive gradient from the east to the west.

Summer and autumn sea surface salinity (SSS) distributions showed great similarity, with average SSS values of 37.3 and 37.0, respectively (Fig. 3).

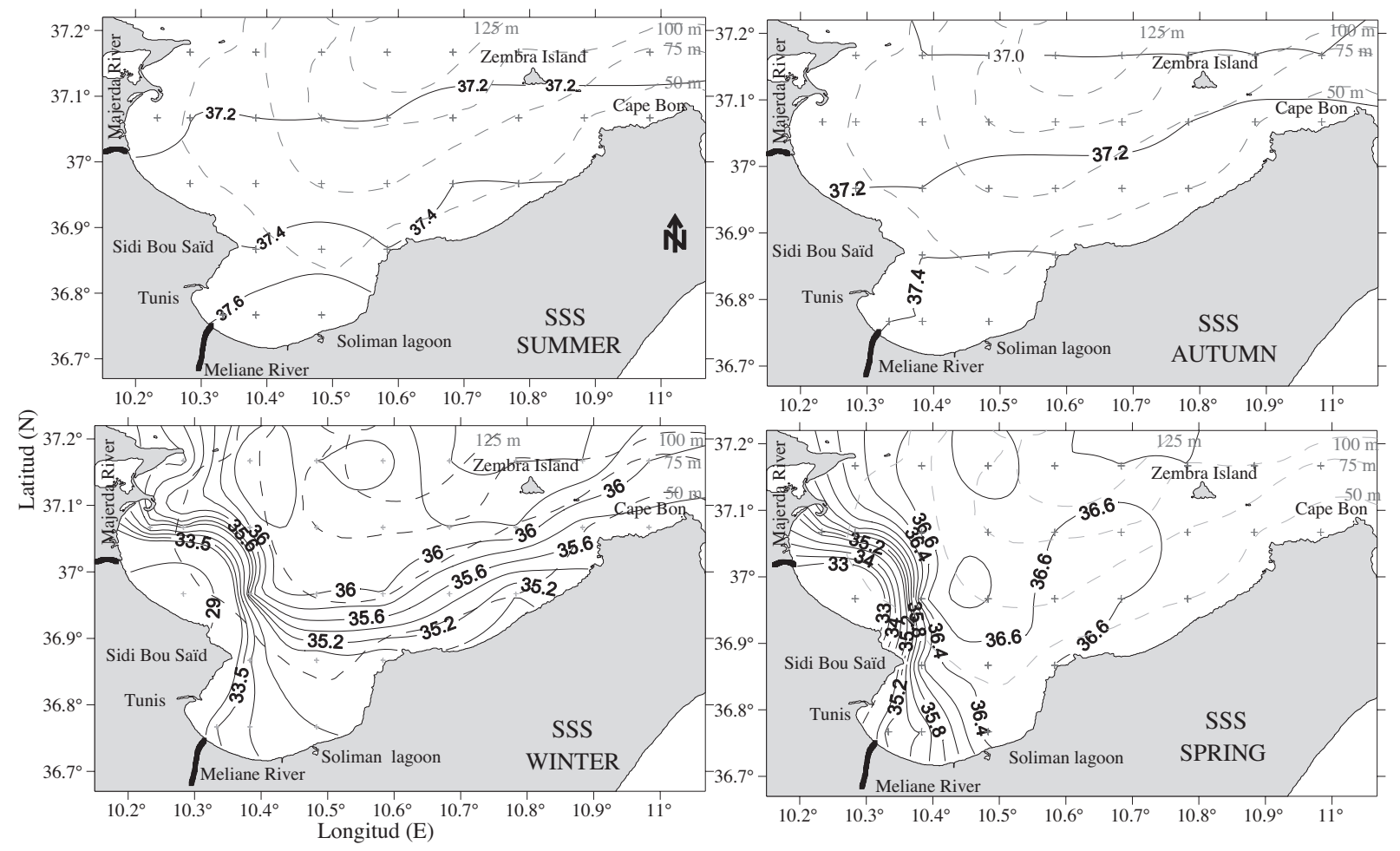

FIG. 3. - Seasonal spatial distribution of sea surface salinity in the Gulf of Tunis. 


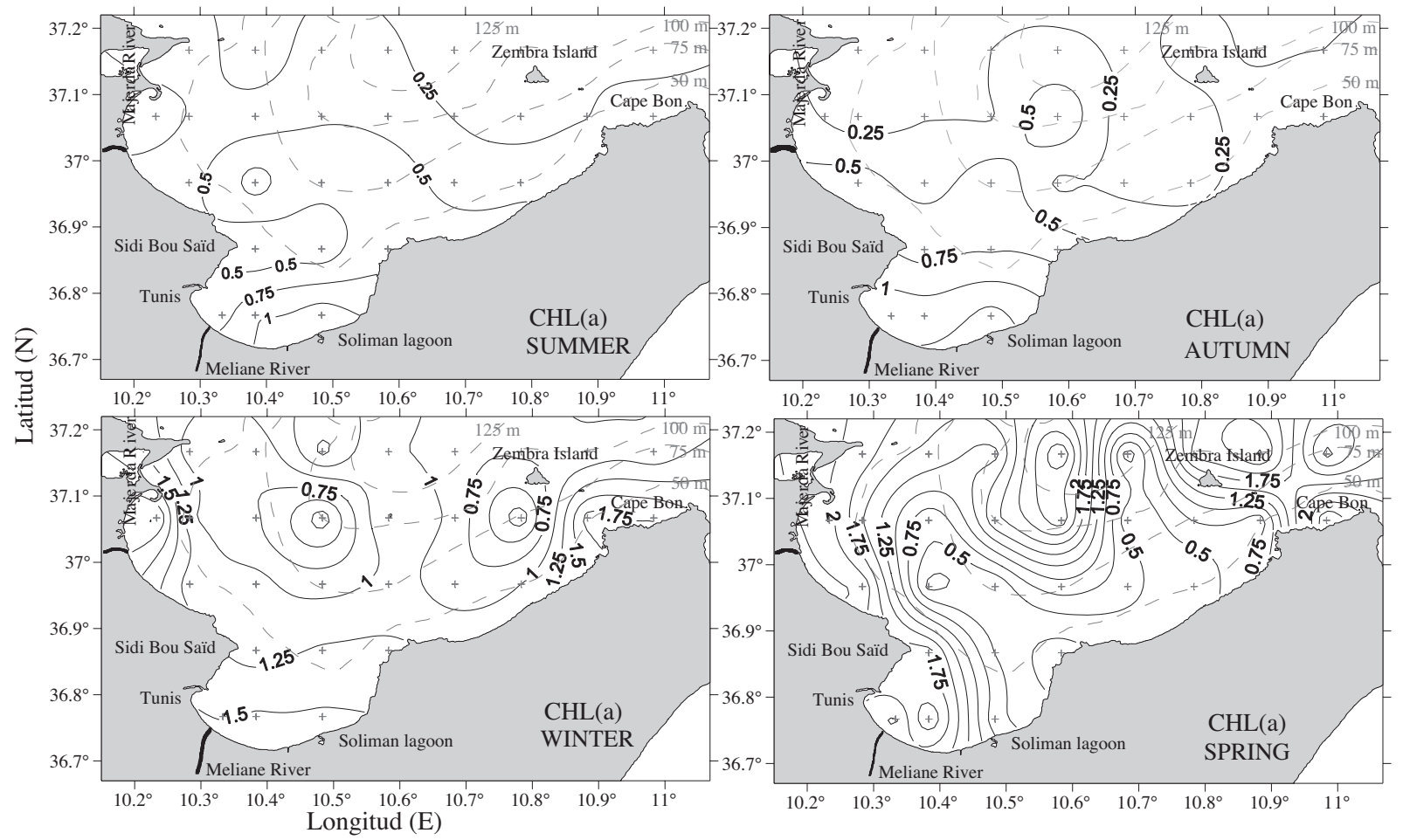

FIG. 4. - Seasonal spatial distribution of chloropyll- $a\left(\mathrm{mg} / \mathrm{m}^{3}\right)$ in the Gulf of Tunis.

For both seasons, weak horizontal variations, with maximum differences of 0.7 in summer and 0.5 in autumn, were observed. In both seasons, saltier waters were located in the inner part of the Gulf as a result of the high evaporation of the coastal waters. The relatively low salinity detected in the northernmost area seems to be related to the Atlantic waters. In winter, the lowest salinity value (22.3) was detected to the south of the River Majreda mouth. A positive gradient was found with a west-east fairly similar, since the lowest salinity value (29.5) was also observed to the south of the River Majreda mouth. However, in the eastern part there was low heterogeneity and no clear gradient. The average SSS was 36.2.

Low concentrations of chlorophyll $a$ at surface were recorded in summer $\left(0.41 \mathrm{mg} / \mathrm{m}^{3}\right)$ and autumn $\left(0.42 \mathrm{mg} / \mathrm{m}^{3}\right)$. For both seasons, relatively high concentrations were found south of the Bay of Tunis, particularly near Soliman lagoon, and the concentrations decreases gradually from south to north (Fig. 4).

In winter and spring, chlorophyll $a$ concentrations increased significantly to average values of 1.11 and $1.26 \mathrm{mg} / \mathrm{m}^{3}$, respectively. In winter, high concentrations (over $1.7 \mathrm{mg} / \mathrm{m}^{3}$ ) were observed near the River Majreda mouth, Cape Bon and the Soliman lagoon. In spring, even higher chloropyll- $a$ concentrations (over $2.7 \mathrm{mg} / \mathrm{m}^{3}$ ) were found once more near the River Majreda mouth and off Cape Bon, but there were high concentrations in the centre of the Gulf and also to the north of Zembra Island.

\section{Egg and larval distributions}

Anchovy eggs were found in all seasons (Fig. 5 and Table 2). However, abundance observed in winter was very low. The highest anchovy egg abundance corresponded to spring, followed by summer (average abundances of 223 and $162 \mathrm{eggs} / 10 \mathrm{~m}^{2}$, respectively). The area southwest of Zembra Island showed a peak of anchovy egg abundance during spring and summer (1255 and 1038 eggs $/ 10 \mathrm{~m}^{2}$, respectively). In summer, no eggs were found on the eastern coasts. However, a relatively high abundance (134 eggs/10 $\mathrm{m}^{2}$ ) was found off the River

TABLE 2. - Range, mean and standard deviation (SD) of anchovy egg and larva abundance by season in the Gulf of Tunis (from summer 2002 to spring 2003).

\begin{tabular}{lcccccc}
\hline & \multicolumn{3}{c}{ Eggs/10 m² } & \multicolumn{3}{c}{ Larvae/10 $\mathrm{m}^{2}$} \\
Season & range & mean & $\pm \mathrm{SD}$ & range & mean & $\pm \mathrm{SD}$ \\
& & & & & & \\
Summer & $0-1038$ & 162 & 279 & $0-445$ & 88 & 129 \\
Autumn & $0-314$ & 47 & 80 & $0-62$ & 13 & 21 \\
Winter & $0-84$ & 7 & 18 & - & - & - \\
Spring & $0-1306$ & 223 & 394 & $0-16$ & 1 & 3 \\
\hline
\end{tabular}




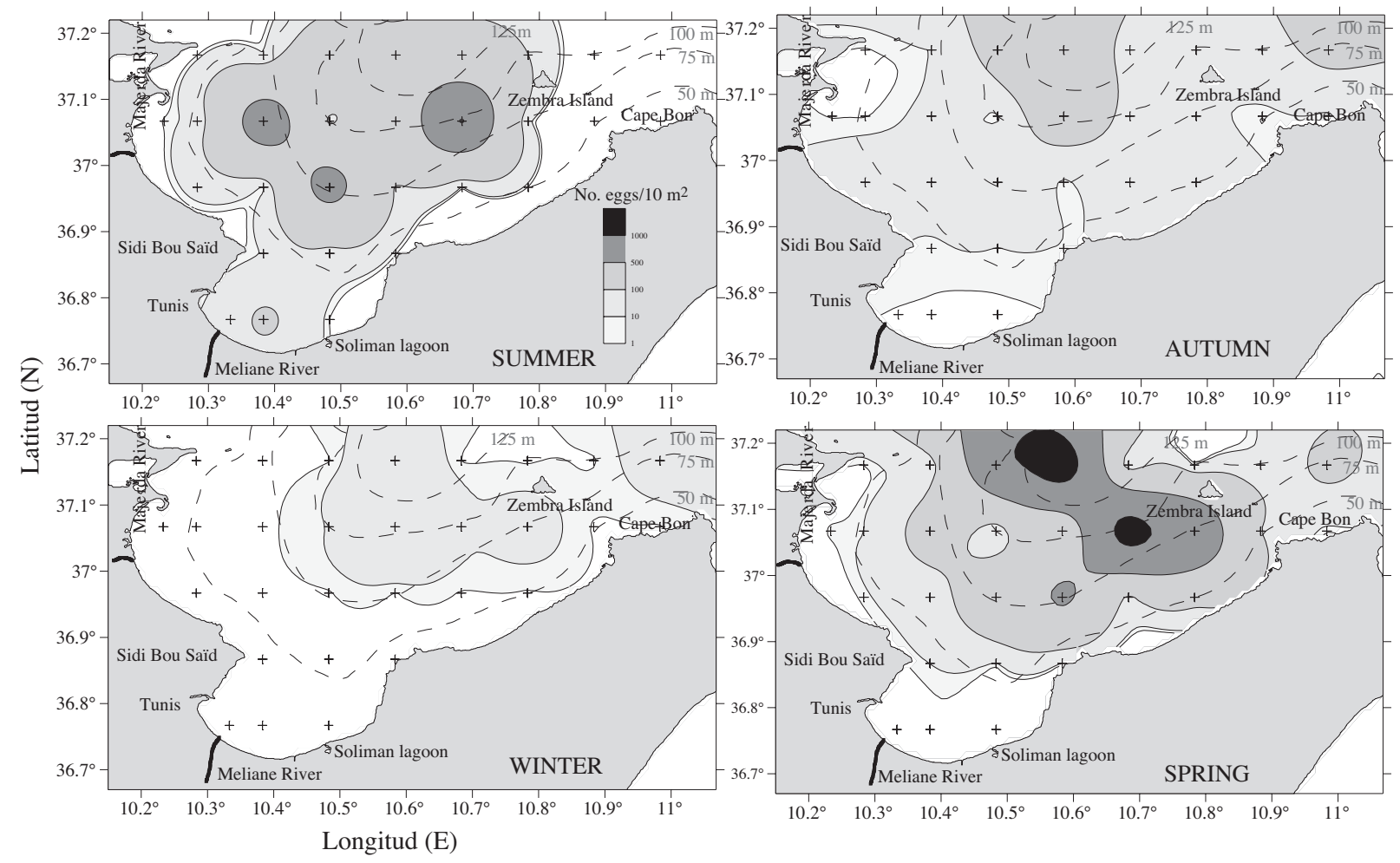

FIG. 5. - Seasonal and spatial distributions of anchovy eggs in the Gulf of Tunis.
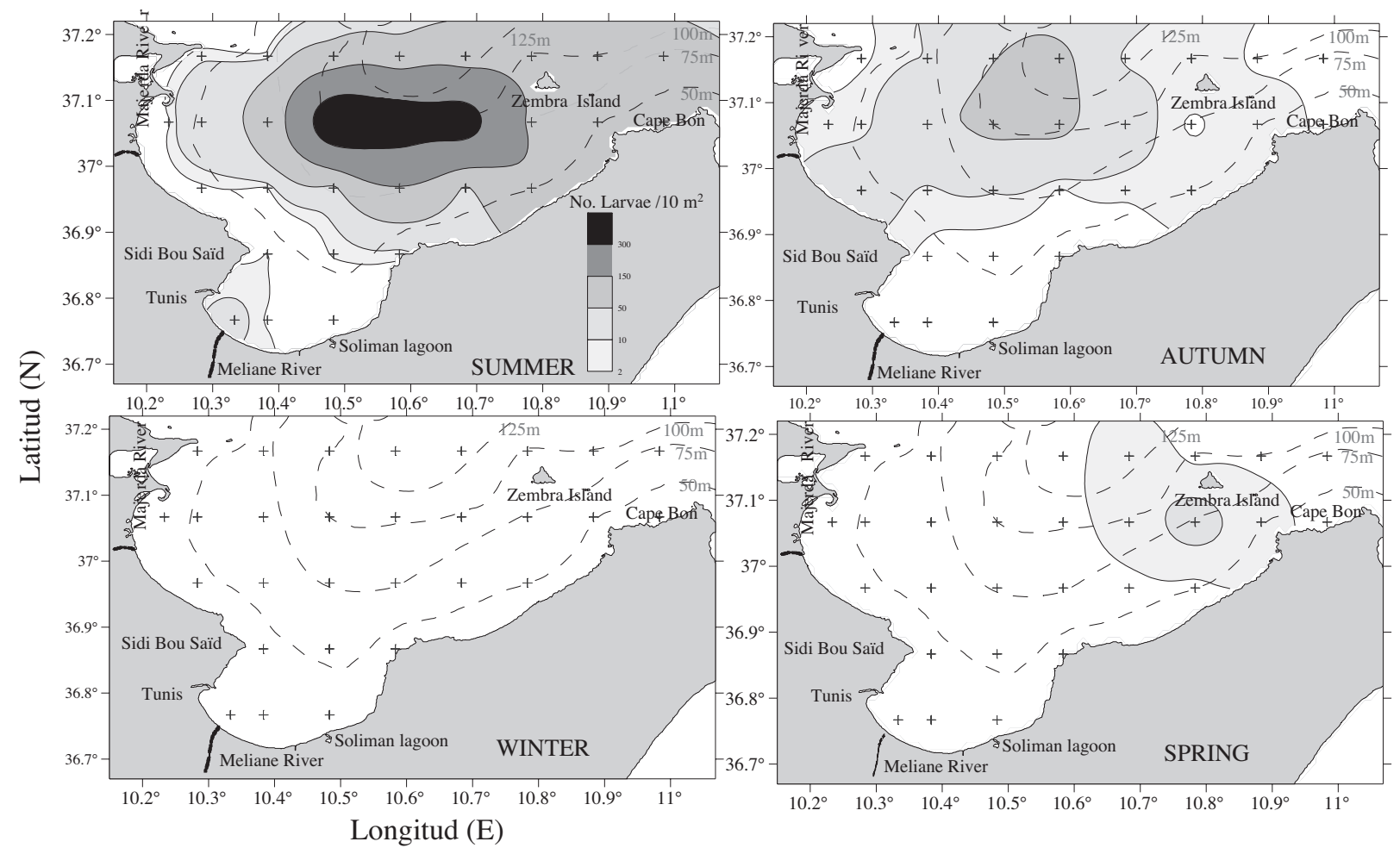

FIG. 6. - Seasonal and spatial distributions of anchovy larvae in the Gulf of Tunis.

Meliane mouth (less than $20 \mathrm{~m}$ in depth). The anchovy egg distribution during autumn showed a wider distribution. Major egg densities were mainly located in the north of the study area, centred in the Gulf of Tunis, showing a gradual decrease in egg abundance towards the coasts. 

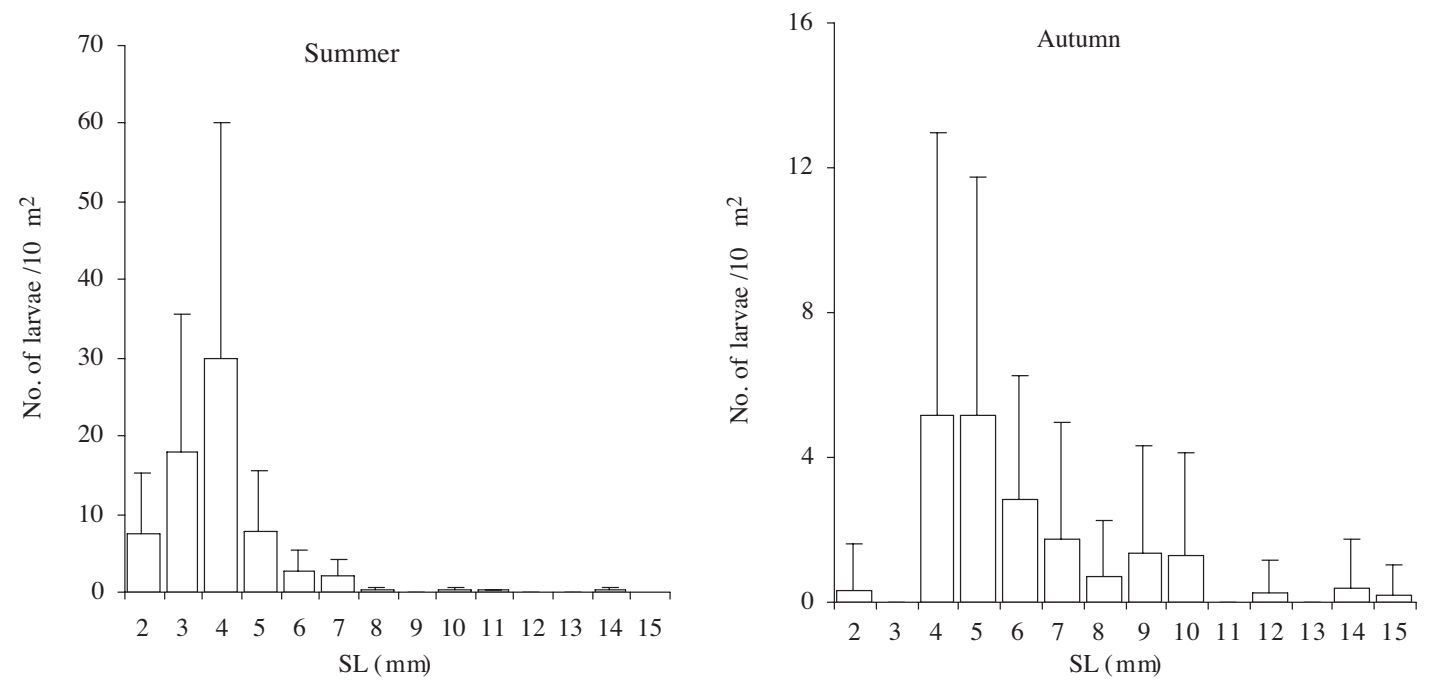

FIG. 7. - Distribution of standard length frequencies (SL) of anchovy larvae in the Gulf of Tunis. Lines denote standard deviation.

Larvae were more abundant in summer (88 larvae $\left./ 10 \mathrm{~m}^{2}\right)$, whereas they were absent in winter and scarce in spring (1 larva/10 $\left.\mathrm{m}^{2}\right)$ (Fig. 6). In summer, they were concentrated (more than 350 larvae $/ 10 \mathrm{~m}^{2}$ ) in the centre of the Gulf. However, an isolated small patch $\left(18\right.$ larvae $\left./ 10 \mathrm{~m}^{2}\right)$ was identified near the River Meliane mouth. As in summer, autumn showed the highest larval abundance $(60$ larvae $/ 10 \mathrm{~m}^{2}$ ) in the centre of the Gulf. A decreasing abundance trend from this point was observed towards the western and eastern coasts. However, no larvae were observed at the southernmost end of the Gulf or in the north off Cape Bon. In spring, larvae were only found to the south and west of Zembra Island with a maximum of 16 larvae $/ 10 \mathrm{~m}^{2}$.

Length (SL) sizes of larvae ranged between 2 and $14 \mathrm{~mm}$ in summer and 2 and $15 \mathrm{~mm}$ in autumn (Fig. 7). Length frequency distributions of larvae showed that in summer the $4 \mathrm{~mm}$ size class was dominant $(43 \%)$ and more than $91 \%$ of larvae were smaller than $6 \mathrm{~mm}$. In autumn, two size classes $(4 \mathrm{~mm}$ and $5 \mathrm{~mm}$ ) dominated, each one representing $27 \%$. More than $44 \%$ of the larvae were larger than $6 \mathrm{~mm}$.

\section{Eggs, larvae and environmental conditions}

In summer, autumn and spring abundances of anchovy eggs and larvae were correlated positively and significantly, the coefficients being 0.41 $(\mathrm{p}=0.047), 0.65(\mathrm{p}=0.000)$ and $0.42(\mathrm{p}=0.026)$, respectively.

There were positive and significant correlations of the depth with the horizontal distribution of anchovy eggs in all seasons, and with larvae in sum-
TABLE 3. - Correlation coefficient between egg distributions and depth $(\mathrm{p}<0,05)$.

\begin{tabular}{lccccc}
\hline & \multicolumn{2}{c}{ Eggs } & \multicolumn{2}{c}{ Larvae } \\
Season & $\mathrm{r}$ & $\mathrm{p}$ & $\mathrm{r}$ & $\mathrm{P}$ \\
\hline & & & & \\
Summer & 0.41 & 0.048 & 0.55 & 0.005 \\
Autumn & 0.58 & 0.001 & 0.53 & 0.003 \\
Winter & 0.38 & 0.044 & - & - \\
Spring & 0.59 & 0.001 & 0.30 & 0.125 \\
\hline
\end{tabular}

mer and autumn (Table 3). Egg abundances showed a negative and significant correlation with salinity in autumn $(\mathrm{r}=-0.44 ; \mathrm{p}=0.016)$ and a positive correlation with temperature in winter $(\mathrm{r}=0.42 ; \mathrm{p}=0.022)$. A negative and significant correlation was observed between larvae abundance and salinity in autumn ( $\mathrm{r}=-0.46 ; \mathrm{p}=0.013)$.

The SST is the main factor controlling the anchovy spawning intensity. The highest egg abundances were found when the SST increased (spring and summer). In contrast, when the SST decreased the egg abundances were low (autumn and winter). For the larvae, the highest abundance was observed when the SST reached its maximum (summer).

In spring, the area of maximum abundance of anchovy eggs coincided with the maximum primary production (chlorophyll $a$ ).

\section{DISCUSSION}

The SST, the SSS and the chlorophyll $a$ distributions in the study area allow us to distinguish two periods: summer-autumn and winter-spring. The 
TABLE 4. - Optimal temperature for anchovy spawning season and peak in Mediterranean Sea and nearest areas.

\begin{tabular}{lclll}
\hline Zone & T optimal $\left({ }^{\circ} \mathrm{C}\right)$ & Spawning season & Spawning peak & Reference \\
\hline Gulf of Biscay & $14-18$ & March-August & May-June & Motos et al. (1996) \\
Mira estuary (Portugal) & $15.5-19.5$ & Mars-November & April & Ré (1996) \\
NW Mediterranean & $15-20$ & April-October & May-July & Palomera, 1992 \\
NW Mediterranean & $15-22$ & April-October & June-August & García and Palomera (1996) \\
Alboran Sea & $19-23$ & Mars-November & August & Rodríguez and Rubin (1986); \\
Ligurian and N Tyrrherian Seas & - & Mai-September & July & Albertelli et al. (1998) \\
$\begin{array}{l}\text { Adriatic Sea } \\
\text { Gulf of Tunis }\end{array}$ & $17-22$ & April-October & May-August & Regner (1996) \\
& $16-25$ & February-October & April-August & Present study \\
\hline
\end{tabular}

first period was characterised by warmer $(25.5$ and $21.8^{\circ} \mathrm{C}$ ), saltier waters (37.3 and 37.2) and lower chlorophyll $a$ concentrations $\left(0.41\right.$ and $\left.0.43 \mathrm{mg} / \mathrm{m}^{3}\right)$. The second period was characterised by colder $(13.4$ and $\left.16.1^{\circ} \mathrm{C}\right)$, lower-salinity waters $(35.1$ and 36.2$)$ and higher chlorophyll $a$ levels (1.11 and 1.27 $\mathrm{mg} / \mathrm{m}^{3}$ ). Moreover, the first period was characterised by horizontal homogeneity and the second by a considerable heterogeneity. The differences observed between these two periods seem to be a result of the Majreda outflow, the air temperature and wind intensity variations.

Despite this temporal variation in the environmental parameters of the Gulf of Tunis, anchovy eggs were caught in all the seasons. However, the main spawning period was spring-summer, when SST ranged between 16.1 and $25.5^{\circ} \mathrm{C}$ between the end and the beginning of the two periods indicated above. Our results agree in general with those exposed by Demir (1965) and Arbault and Boutin (1977), who stated that the most favourable temperature range for anchovy spawning was 15 to $25^{\circ} \mathrm{C}$ and 15.8 to $24^{\circ} \mathrm{C}$, respectively. However, anchovy spawning can occur with the minimum temperature of $13^{\circ} \mathrm{C}$ (Dekhnik, 1954; Demir, 1959; Palomera, 1992), as occured in the present winter survey $\left(13.4^{\circ} \mathrm{C}\right)$. Moreover, in the northern Adriatic sea, Zavodnik (1970) caught anchovy eggs in February with water temperatures of $11.6^{\circ} \mathrm{C}$. Our results also agree with those found by Motos et al. (1996) and Palomera (1992), in the sense that the anchovy spawning peak takes place in the transition period between winter (cold and vertically homogenous waters) and summer (warm and stratified waters), the abundance of anchovy eggs and larvae being positively correlated to the warming rate of surface waters.

The spawning period of anchovy shows some differences among Mediterranean regions, but in all cases Engraulis encrasicolus showed the maximum spawning intensity in spring and/or in summer, as can be seen in Table 4 . The wide spawning period observed in the present study could be explained by the temporal difference in the spawning of different cohorts. Cendrero et al. (1981) and Santiago and Eltink (1988) demonstrated that the young specimens ( 1 year) spawn in June and the older (2 years and more) spawn early, in April and May. Moreover, García and Palomera (1996) concluded that the spawning period of anchovy is longer in southern latitudes of the Mediterranean (seven months) than in northern ones (five months).

The spawning grounds of Engraulis encrasicolus in nearby areas are usually related to places where enrichment processes occur: fronts, upwellings, convergence areas and river runoff (Motos et al., 1996; Palomera, 1992; Bakun and Agostini, 2001; Agostini and Bakun, 2002; GarcíaLafuente et al., 2002; Cuttita et al., 2004). In our case the period with maximum abundance of anchovy eggs (spring) coincided with the maximum primary production (highest measured concentrations of chlorophyll $a$ ).

In many places anchovy spawning is associated with river outflows (Richardson, 1981; Lima and Castello, 1995), as occurs in the northwestern Mediterranean with the Rivers Ebro and Rhone (Aldebert and Tournier, 1971; Palomera, 1992; Palomera and Sabatés, 1990) and in the Bay of Biscay with the Loire and the Garonne (Arbault and Boutin, 1977). Demir (1965) indicated a wider tolerance for this species, between 9 and 37. Taking into account these references, it seems that the Gulf of Tunis could be a favourable spawning habitat for anchovy thanks to the enrichment produced by the outflow of the Rivers Majreda and Meliane. However, in our case during the main spawning period (spring) eggs and larvae were absent or scarce in the areas with lower salinities (29.5), and there was a negative correlation between egg distri- 
bution and SSS. These discrepancies could be related to the fact that the area affected by these waters with lower salinity is located very close to the coast, in areas probably too shallow for the distribution of anchovy adults.

The larval abundance was higher and larvae were more widely distributed in summer and autumn, when the surface water column is more stable. On the other hand, abundance in spring was low and larvae were concentrated in the eastern part of the Gulf. The lower larval abundance in spring, despite the high abundance of eggs, seems to be related to the sea surface temperature $\left(16.1^{\circ} \mathrm{C}\right)$. The development time of anchovy eggs decreases from 38 hours at $19^{\circ} \mathrm{C}$ to 30 hours at $21^{\circ} \mathrm{C}(\mathrm{Lo}, 1985)$. Thus, this low temperature may have extended the anchovy egg development time, reducing the intensity of hatching and affecting the egg survival since eggs are highly prone to predation (Alheit, 1987).

The maximum larval abundances were found in the deeper (more than $50 \mathrm{~m}$ ) areas of the north part of the Gulf. The main distribution zone for Engraulis encrasicolus eggs in the northwestern Mediterranean has been reported at depths higher than $100 \mathrm{~m}$ (Palomera and Sabatés, 1990; Olivar et al., 2001).

The spawning areas and larval abundance in the Gulf of Tunis seem to be related to the central part of the Gulf, beyond the $75 \mathrm{~m}$ isobath. Despite the Majreda outflow-induced enrichment processes that occur in spring, the main spawning areas were far offshore. It is likely that in the north of the gulf there were some other enrichment processes not detected at the surface. A similar situation were found in the area of the Ebro river delta, where although the productivity induced by the outflow of the river is great over the continental shelf, the high abundances of anchovy eggs are always found at the limit of the shelf, where a deep chlorophyll $a$ maximum is always observed between 50 and $70 \mathrm{~m}$ depth in the summer months (Palomera, 1992, Olivar et al., 2001).

This work is a first step that needs to be followed by others in order to obtain a better understanding of recruitment fluctuations of Tunisian anchovy populations. Indeed, it is necessary to analyse the relationships between abundances of early life stages of anchovy and more environmental parameters, to extend the study area in order to cover the whole spawning area of the stock, and to carry out multiyear studies.

\section{ACKNOWLEDGEMENTS}

The authors are very grateful to the crew of the R/V Hannibal of the Institut National des Science et Technologies de la Mer (INSTM) for their collaboration, which facilitated our work during the surveys, and to the technical staff of Marine Resources and Marine Environment Laboratories of INSTMLa Goulette for their active participation. Many thanks are due to Isabel Palomera, M. Pilar Olivar and the anonymous referee for critically reviewing the manuscript and providing many helpful suggestions.

\section{REFERENCES}

Agostini, V.N. and A. Bakun. - 2002. 'Ocean triads' in the Mediterranean Sea: physical mechanisms potentially structuring reproductive habitat suitability (with example application to European anchovy, Engraulis encrasicolus). Fish. Oceanogr. 11(3): 129-142.

Albertelli, G., M.I. Angelino, N. Della Croce and P. Salemi Picone. 1988. Valutazione delgi stocks di acciughe e parametri aminetali in Mar Ligure. Atti Seminari UU. OO. Responsabili progetti ricerca promossi nell ambito shema preliminare di piano per la pesca e aquacultura. M.M.M. CNR Roma, 1: 89-97.

Aldebert, Y. and H. Tournier. - 1971. La reproduction de la sardine et de l'anchois dans le golfe de Lion. Rev. Trav. Inst. Pêches marit., 35(1): 57-75.

Alheit, J. - 1987. Egg cannibalism versus egg predation: their significance in anchovies in the Benguela and comparable systems. S. Afr. J. mar Sci. 5: 467-470.

Arbault, S. and N. Lacroix-Boutin. - 1977. Eufs et larves de Clupeides et Engraulides dans le golfe de Gascogne (1969-1973) Distribution des frayères. Relations entre les facteurs du milieu et la reproduction. Rev. Trav. Pêches marit. 41(3): 227-254.

Bakun, A. and V. Agostini. - 2001. Seasonal patterns of wind-driven upwelling/ downwelling in the Mediterranean Sea. Sci. Mar., 65(3): 243-257.

Ben Abdallah, L. and A. Gaamour. - 2004. Répartition géographique et estimation de la biomasse des petits pélagiques des côtes tunisiennes. In: D. Levi, T. Bahri, G. Basilone, L. Ben Abdallah, A. Bonanno, A. Gaamour, B. Patti and R. Zarrad (eds.), Rep. Expert Consulting on Small Pelagic Fishes, stock identification and oceanographic processes influencing their abundance and distribution. MedSudMed Tech. Doc. n5: 48-66.

Borja, A., A. Uriarte, J. Egana, L. Motos and V. Valencia. - 1998. Relationships between anchovy (Engraulis encrasicolus) recruitment and environment in the Bay of Biscay (1967-1996). Fish. Oceanogr. 7(3-4): 375-380.

Cendrero, O., J.L. Cort and E. de Cardenas. - 1981. Revision de algunos datos sobre la biologica de la anchoa (Engraulis encrasicolus L.) del mar Cantábrico. Bol. Inst. Esp. Oceanogr., 6: $117-124$

Cuttitta, A., V. Carini, B. Patti, A. Bonanno, G. Basilone, S. Mazzola, J. García-Lafuente, A. Garcia, G. Buscaino, L. Aguzzi, L. Rollandi, G. Morizzo and C. Cavalcante. - 2004. Anchovy egg and larval distribution in relation to biological and physical oceanography in the Strait of Sicily. Hydrobiologia, 527(1): 177-182.

Dekhnik, T.V. - 1954. Spawning of anchovy and grey mullet in the Black Sea. Alluniov Sci. Inst. Mar. Fish. Oceanogr., 28: 34-48.

Demir, N. - 1959. Notes of the variations of eggs of anchovy (Engraulis encrasicolus L.) from Black Sea, Marmara, Agean and Mediterranean Seas. Pub. Hydrobiological Res. Inst., Fac. Sci., Univ. Istanbul, 4: 180-187.

Demir, N. - 1965. Synopsis of biological data on anchovy 
Engraulis encrasicolus (Linnaeus, 1758) (Mediterranean and adjacent seas). FAO Fish. Synop., (26) Rev. 1: 42 p.

DGPA (Direction Générale de la Pêche et de l'Aquaculture). 1999-2004. Annuaires des Statistiques des Produits de la Pêche en Tunisie.

García, A. and I. Palomera. - 1996. Anchovy early life history and its relation to surrounding environment in the western Mediterranean Basin. In: I. Palomera and P. Rubiés (eds.) The European anchovy and its environment. Sci. Mar., 60(Suppl. 2): $155-156$.

García-Lafuente, J., A. García, S. Mazzola, L. Quintanilla, J. Delagado, A. Cuttita, and B. Patti. - 2002. Hydrographic phenomena influencing early life stages of the Sicilian Channel anchovy. Fish. Oceanogr., 11 (3): 31-44.

Ktari-Chakroun, F. - 1979. Distribution des aires de ponte de l'anchois le long des côtes tunisiennes et des canaux Tuniso-sarde et Siculo-tunisien. Rapp. Comm. int. Mer Médit., 25-26(10): $189-190$.

Lima, I.D. and J.P. Castello. - 1995. Distribution and abundance of south-west Atlantic anchovy spawners (Engraulis anchoita) in relation to oceanographic processes in the southern Brazilan shelf. Fish. Oceanogr. 4: 1-16.

Lloret, J., I. Palomera, J. Salat and I. Sole. - 2004. Impact of freshwater input and wind on landings of anchovy (Engraulis encrasicolus) and sardine (Sardina pilchardus) in shelf waters surrounding the Ebre (Ebro) River delta (north-western Mediterranean). Fish. Oceanogr. 13(2): 102-110.

Lo, N.C.H. - 1985. A model for temperature-dependent northern anchovy egg development and an automated procedure for the assignment of age to stage eggs. In R. Lasker (ed.). An egg production method for estimating spawning biomass of pelagic fish: Application to the northern anchovy, Engraulis mordax. NOAA Tech. Rep. NMFS 36: 43-50.

Lorenzen, C.J. - 1967. Determination of chlorophyll and phaeopigments: spectrophotometric equations. Limnol. Oceanogr., 12: 343-346.

Motos, L., A. Uriarte and V. Valencia. - 1996. The spawning environment of the Bay Biscay anchovy (Engraulis encrasicolus L.). In: I. Palomera and P. Rubiés (eds.), The European anchovy and its environment. Sci. Mar., 60(Suppl. 2): 117-140.

Olivar, M.P., J. Salat and I. Palomera. - 2001. Comparative study of the spatial distribution patterns of the early stages of anchovy and pilchard in the NW Mediterranean Sea. Mar. Ecol. Progr. Ser., 217: 111-120.

Palomera, I. - 1992. Spawning of anchovy Engraulis encrasicolus, in the north-western Mediterranean relative to hydrographic features in the region. Mar. Ecol. Prog. Ser., 79: 215-223.

Palomera, I. and A. Sabatés. - 1990. Co-occurrence of Engraulis encrasicolus and Sardinella aurita eggs and larvae in the northwestern Mediterranean. Sci. Mar., 54(1): 61-67.

Ré, P. - 1996. Anchovy spawning in the Mira estuary (southwestern Portugal). In: I. Palomera and P. Rubiés (eds.), The European anchovy and its environment. Sci. Mar., 60(Suppl. 2): 141-153.

Regner, S. - 1996. Effects of environmental changes on early stages and reproduction of anchovy in the Adriatic Sea. In: I. Palomera and P. Rubiés (eds.), The European anchovy and its environment. Sci. Mar., 60(Suppl. 2): 167-177.

Richardson, S.L. - 1981. Spawning biomass and early life of northern anchovy, Engraulis mordax, in the northern subpopulation off Oregon and Washington. Fish. Bull., 78: 855-876.

Rodríguez, J.M. - 1990. Contribution al conocimiento del ictioplancton del mar de Alborán, Bol. Inst. Esp. Oceanogr., 6: 1-20.

Rodríguez, J.M. and J.P. Rubin. - 1986. The sardine and anchovy ichthyoplankton captured in nine fixed stations located at the Bay of Malaga from May to December of 1977. Rapp. Comm. int. Mer Médit., 30, 2.

Sabatés, A., J. Salat and M.P. Olivar. - 2001. Advection of continental water as an export mechanism for anchovy, Engraulis encrasicolus, larvae. Sci. Mar., 65(Suppl. 1): 77-87.

Sammari, C., C. Millot, I. Taupier-Letage, A. Stefani and M. Brahim. - 1999. Hydrological characteristics in the TunisiaSardinia-Sicily area during spring 1995. Deep Sea Res. I, 46: 1671-1703.

Santiago, J. and A. Eltink. - 1988. Distribution and abundance of anchovy eggs in the Bay of Biscay in May 1987 in comparison to 1983 and 1986. ICES, C. M.: H: 9.

Smith, P.E. and S.L. Richardson. - 1977. Standard techniques for pelagic fish eggs and larval survey. FAO Fish. Tech. Pap. No.175, 100pp.

Zarrad, R. - 2001. Contribution à l'étude de l'ichtyoplancton dans le golfe de Tunis. Diplôme des Etudes Approfondies de l'INAT, Tunisie.

Zavodnik, D. - 1970. Comparative data on the spawning of sardine (Sardina pilchardus Walb.), sprat (Sprattus sprattus L.) and anchovy (Engraulis encrasicolus L.) in the north Adriatic. Ichthyologica, 2: 171-178.

Received November 14, 2005. Accepted April 27, 2006.

Published online September 26, 2006. 